\title{
A test of the impact of mergers on bank competition
}

\author{
Vittoria Cerasi $^{1}$ | Barbara Chizzolini ${ }^{2}$ | Marc Ivaldi ${ }^{3}$
}

\author{
${ }^{1}$ Department of Economics, Management and \\ Statistics (DEMS) and Center for European \\ Studies (CefES), Bicocca University, Milano, \\ Italy \\ ${ }^{2}$ Department of Economics, Bocconi \\ University, Milan, Italy \\ ${ }^{3}$ Toulouse School of Economics (EHESS), \\ Manufacture des Tabacs - Batiment F, \\ Toulouse, France

\section{Correspondence} \\ Vittoria Cerasi, Department of Economics, \\ Management and Statistics (DEMS) and \\ Center for European Studies (CefES), Bicocca \\ University, Piazza dell'Ateneo Nuovo 1, \\ 20126 Milano, Italy. \\ Email: vittoria.cerasi@unimib.it
}

\begin{abstract}
We propose a new test to evaluate the impact of horizontal mergers on competition in the banking industry. The test is designed to be applied ex ante to potential mergers while being parsimonious in terms of data, as it only uses information on branches in local markets. The test is a counterfactual exercise based on a two-stage model where banks compete in branching and interest rates and requires comparing the estimated degree of competition in the status quo, where branching networks by banks are those actually observed, with a counterfactual scenario, where the branching network of the new entity is the sum of the branches of the banks involved in the horizontal merger. The statistical difference between the two estimated measures of competition quantifies the impact of the merger. We apply our test to French and Italian mergers.

\section{KEYWORDS}

banking industry, competition and market structure, merger policy

JEL CLASSIFICATION

G21 (banks), L13 (oligopoly), L59 (regulation and industrial policy)
\end{abstract}

\section{1 | INTRODUCTION}

Following the influential work of Bain (1956), the Structure-Conduct-Performance paradigm has affected the way we measure the impact of horizontal mergers on competition. Horizontal mergers are usually considered detrimental to competition because they could increase the market power of involved firms. In industries with a high degree of concentration, where a larger percentage of market shares is controlled by few firms, collusion is indeed very likely to occur. A simple measure of concentration, such as the Herfindahl-Hirschman Index (HHI), in those industries is enough to predict how the conduct and the performance of firms will change following a merger. 
However, in fragmented industries where many firms coexist with a single dominant firm, a merger between smalland medium-sized players might improve competitive conditions by creating a new rival, large enough to stand against the incumbent firm (see Berger, Demirgiuc-Kunt, Levine, \& Haubrich, 2004; Cetorelli, 1999; Dick, 2007). In this case, a rise in the degree of concentration, as measured by market shares, might enhance competition, and more sophisticated tools rather than a simple measure of concentration are needed to understand the effect of mergers on competition.

This paper contributes to this analysis by proposing a new test to assess the impact of horizontal mergers on the degree of competition in the banking industry. ${ }^{1}$ The present paper departs from Cerasi, Chizzolini, and Ivaldi (2002) where we proposed a structural model to estimate competition in the banking industry. The novelty, here, is in the use of the same structural model to perform a counterfactual exercise on a bank merger, where we compare the status quo to an artificial scenario as if the merger was approved. First, we estimate the degree of competition in the status quo, using the observed branching size of banks in each local market. Then, we build a counterfactual scenario, where we imagine that two or more banks are allowed to merge, giving rise to a new entity, whose branching network is the sum of the branches of the merging banks, whereas the market size and the overall number of branches are kept constant at market level. In both cases, we derive a measure of competition following the latent variables' approach developed in Cerasi et al. (2002), that is, estimating the elasticity of bank profits to branching size. We derive the impact assessment of the merger on competition from the comparison of the two measures.

Our test is based on available public data on banking industries, the same type of information used to compute the $\mathrm{HHI}$ in merger assessments, when instead disaggregated accounting records are not available to scholars. The test is then applied to France and Italy. The two countries show significant differences in their banking structures. In France, all major banking groups compete with each other in almost all local markets. In Italy, only a few banking groups have a branching network with a national reach, whereas the majority are local banking groups. The differences between these banking structures offer an interesting framework to apply our test. More in detail, in France, we consider the impact on competition of the merger between Credit Agricole (CA) and Credit Lyonnais (CL) and between Credit Mutuel (CM) and Credit Industriel Commercial (CIC), whereas in Italy we analyse the impact of the merger between Intesa (IN) and San Paolo IMI (SP) and between UniCredito (UN) and Capitalia (CP). The results indicate significant changes in competition, by comparing the status quo to our counterfactual scenario, at the local market level. More interestingly, the direction of these changes may be either anti- or pro-competitive.

According to our exercise, the French mergers have a procompetitive effect, whereas the Italian mergers are anticompetitive. In France, in most local markets, those mergers create at least a new entity, large enough to compete with the incumbent banks. In Italy, on the contrary, the two mergers reduce substantially the number of large players, at least, in some local markets. These contrasting effects cannot be fully anticipated by focusing just on the changes in market concentration, even when measured locally, because in both cases the HHI rises. Our measure correctly detects these asymmetric effects, by capturing changes in competition endogenously determined from the modified market structures. We thus believe that our test provides useful guidance to competition authorities who must assess ex ante, before their approval, the impact of mergers in industries where the retail network is an important strategic device, as in the banking industry, basing their assessment on publicly available data.

\section{1 | Related literature}

There exist a vast number of paper on the consequences of horizontal mergers using structural models of monopolistic competition based on detailed firm-level data (see the survey in Budzinski \& Ruhmer, 2010). The majority of these papers computes the postmerger prices and quantities on the basis of premerger estimated

${ }^{1}$ Understanding the effects of mergers on competition is of particular interest for banks where concentration is pursued for stability reasons, forgoing possible anticompetitive effects (see Bikker \& Haaf, 2002; Carletti \& Vives, 2009; Degryse \& Ongena, 2008; and among others). 
demand and supply parameters. In the banking industry, this is done by substituting into the premerger structural equations, the sum of the branches for the new entities (see, e.g., Barros, Bonfim, Kim, \& Martins, 2014; Molnar, 2008; Zhou, 2008; among others). Such a procedure rests on the assumptions that "... the form of competition, the demand system and the functional form of marginal cost do not change due to the merger ..." as noted by Budzinski and Ruhmer (2010).

Within this approach, Barros et al. (2014) perform an interesting counterfactual analysis to disentangle the effect of mergers from the influence of other macro-economic factors, exploiting a wave of mergers that occurred in 2000 in Portugal. Using a structural model, they derive the estimated coefficients of the demand and supply of credit in the premerger equilibrium. Then, they build a counterfactual scenario where they keep all the macro-economic factors at their premerger values, but use the observed new branching size of banks after the mergers to get an estimate of the amount of credit and interest rates that would have occurred in the absence of the macro-economic factors. From the comparison of the observed postmerger values to the estimated values in their counterfactual scenario, they are able to decompose the effects on credit and interest rates due to the merger (that affected branching networks and market structure) and the changes due to macro-economic or other external factors. In addition, they measure the degree by which each bank internalises the profits of other banks, showing that the high degree of competition estimated before the merger is preserved even after the merger. In our counterfactual exercise, we also use a structural model of branching behaviour of banks and a measure of bank competition directly derived from the model, although evaluating the merger before its occurrence, we cannot base our assessment on postmerger data.

Our paper overcomes the rather strong assumptions of the mentioned papers by jointly modelling changes in market structure and degree of competition due to mergers using a modified version of the approach used in Bresnahan and Reiss (1991a), Berry and Tamer (2006) and Schaumans and Verboven (2015). Moreover, our empirical model is based on a reduced form of profits, a function of both market- and firm-specific observable variables. This implies that our test does not need accounting data, often unavailable at firm and market levels.

Several papers study the impact of horizontal mergers of banks on the amount of credit to firms (Focarelli \& Panetta, 2003; Sapienza, 2002; to cite just a few), on the value for shareholders (Carletti, Ongena, Siedlarek, \& Spagnolo, 2015; De Young, Evanoff, \& Molyneux, 2009) and on market structure (Adams, Johnson, \& Pilloff, 2009). Their evidence on the effect of mergers on banks' market power is mixed. All these papers apply different methods to postmerger data. Our aim is instead to carry an ex ante assessment to approve or reject the merger before the merger occurs.

Finally, note that our approach can easily be transferred to other industries where the retail network is important, for instance, insurance, grocery chain stores or car dealers. ${ }^{2}$

The remainder of the paper is organised as follows. In Section 2, we explain the econometric specification based on the branching behaviour of banks in each local market and the design of our empirical test. The description of our sample data on French and Italian banking groups is presented in Section 3. In Section 4, we apply our test to Italian and French mergers and discuss the impact of those mergers on the degree of competition at the local market level. Section 5 concludes the paper. The technical details of the estimation method and identification strategy are contained in Section A.1.

\section{2 | ECONOMETRIC SPECIFICATION}

We develop, here, the main elements of our test, which is based on the same empirical specification developed in Cerasi et al. (2002). There we derive a measure of competition that can be estimated from a two-stage model of monopolistic competition with banks competing on financial services through branching networks. The novelty, here, consists in exploiting the same empirical specification within a counterfactual exercise to predict ex ante the effect of mergers.

\footnotetext{
${ }^{2}$ See, for instance, Dafny (2009) for an application outside the banking industry to assess the impact of mergers among hospitals.
} 
In this section, we analyse the two elements at the base of our empirical approach. First, we review our empirical specification to understand how we derive an estimated measure of bank competition; then, we explain the counterfactual exercise to evaluate ex ante the impact of a merger, at the base of our test.

Retail banks compete for customers through branches when selling a bundle of financial services. ${ }^{3}$ Banks locate their branches in a market in anticipation that their total entry and operating costs will be covered by the profit in that specific market. In turn, the profits of a branching network of given size are affected by the intensity of competition that each bank anticipates in a specific market: The tougher the competition, the smaller the expected gain from a network of a given number of branches. Banks tend to locate fewer branches in those markets where they anticipate tougher competition. Thus, the elasticity of profits with respect to an additional branch, ceteris paribus, must be inversely correlated with the intensity of competition in that specific market.

More formally, we assume that each incumbent bank $i$ is characterised by the following reduced form for the (log) profit in market $j:{ }^{4}$

$$
\ln \pi_{i j}=\ln S_{j}-\frac{1}{2} \ln N_{j}+c c i_{j} \ln k_{i j}
$$

The per-market bank profit is increasing in the size of the market, $S_{j}$, capturing total volume of trade, while decreasing in the total number of branches owned by all banks in that specific market, $N_{j}$, including the branches of bank $i$ in market $j$, that is, $k_{i j}$.

The measure of how much bank profit increases when opening a new branch is captured by the elasticity of gross profits to branching, that is to say, $c c i_{j}$ in our specification. ${ }^{5}$ We claim that this elasticity is related to the degree of competition in the local market. When we observe that a bank owns a branching network larger in market $A$ than that in market $B$, we may infer, ceteris paribus, that in market $A$ competition is softer than that in market $B$. Therefore, opening a new branch in market $A$ must be, ceteris paribus, more profitable than in market $B$. To summarise, greater competition for financial services in a market must be associated to a lower elasticity of profits with respect to branching. The inverse of cci is the measure of the degree of competition that plays an important role in what follows.

Each bank sets its optimal branching size by maximising the profit in (1) with respect to $k_{i j}$, taking the branching size of the rivals as given. At the Nash equilibrium, bank i's branching decision in market $j$ is the best reply to rivals' choices in that market.

The Nash equilibrium is defined by a set of first-order conditions holding for each bank $i$ in market $j$, namely the equality between marginal benefits $(\mathrm{MB})$ and marginal costs $(\mathrm{MC})$ of branching (that we assume to be constant in what follows). Formally, taking the partial derivative of the profit function (1), we obtain the left-hand side of the following equilibrium condition for each bank $i$ in market $j$ :

$$
M B_{i j}=M C_{i j}
$$

whenever $k_{i j}>1$. For unit banks, namely when $k_{i j}=1$, it must be that the marginal benefit of opening an additional branch in addition to the headquarters (the first branch) is smaller than its marginal cost.

\footnotetext{
${ }^{3}$ Branching is still an important strategic device in retail banking markets for our sample period before the development of the online banking. Moreover, the geographic proximity represents a competitive advantage when monitoring loans of opaque small and medium entreprises (SMEs), as argued in Petersen and Rajan (2002), Degryse and Ongena (2005), Brevoort and Hannan (2006) and Dick (2007).

${ }^{4}$ We refer to Cerasi et al. (2002) for the theoretical model at the basis of this empirical specification. In the two-stage model, we assume that banks determine their branching network size in each market in the first stage, while competing on the price of their financial services in the second stage. The ad hoc reduced form of profits in the first stage of the game is similar to that in the empirical literature on entry led by Bresnahan and Reiss (1991a, 1991b), although in our case we have chosen to add restrictions on the parameters of the log-linear specification, to stick to the underlying theory and to explicitly identify one of the free parameters as a measure of the degree of competition. Schaumans and Verboven (2015), among others, estimate a competition parameter with an interpretation very similar to our measure of degree of competition, although they estimate a market revenue function separately from each firm's profit function. A similar approach can be found in Cohen and Mazzeo (2007), Boone (2008), Boone, van Ours, and van der Wiel (2007) and De Juan (2008) where a structural model is used to estimate the degree of bank competition.
}

${ }^{5}$ More precisely the elasticity is given by $\partial \ln \pi_{i j} / \partial \ln k_{i j}=c c i j-k_{i j} / 2 N_{j}$. 


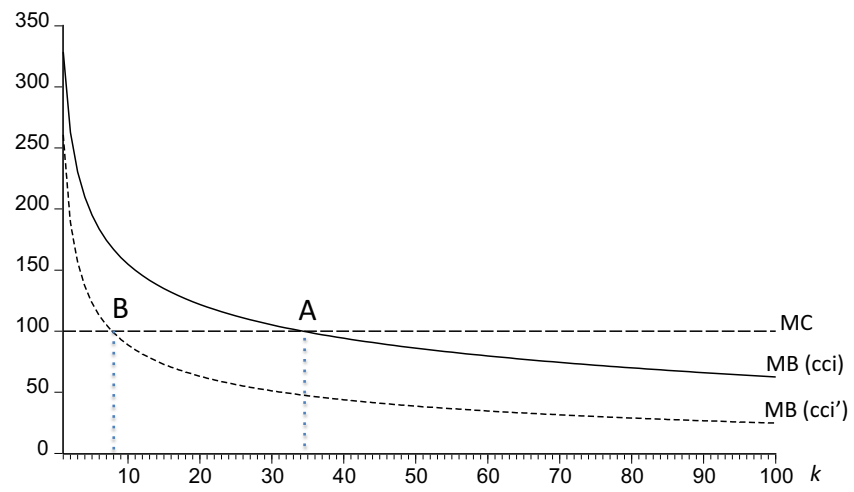

FIGURE 1 Equilibrium branching size is in Point $A$ where the line $M C$ intersects the curve MB. Note. If cci decreases (greater competition in prices) to $c c^{\prime}$, then the curve MB shifts down. The new equilibrium moves to Point $\mathrm{B}$, where the number of branches is smaller

We provide a graphical representation of the equilibrium branching size for an increasing competitive pressure in a market in Figure 1.

Here, we draw the functions marginal cost of branching $(M C)$ and marginal benefit of branching $(M B)$ for a changing number of branches $k$, assuming that the $M C$ function is a constant line, whereas the $M B$ function is decreasing in the number of branches, due to the fading effect on profits of a larger branching network. The equilibrium level of branches is in Point A, where, according to condition (2), MB equates MC. For any branching network size, when cci decreases (i.e., increasing competitive pressure), the $M B$ schedule shifts downwards. For given $M C$, this reduces the number of branches for each bank because the equilibrium moves to Point $B$.

Note that, in this exercise, the degree of competition cci is exogenously given and affects the marginal benefits of branching, whereas it does not affect the marginal cost. In this framework, a tougher price competition has, ceteris paribus, an unambiguous negative impact on branching size: For a given market size and the number of competitors, if competition is tougher (lower elasticity of gross profits to branching), we expect banks to have fewer branches, due to the lower expected gain of a branching network of given size.

When moving to the econometric test, the assumption that the marginal cost of branching is constant and the degree of competition is exogenous must be relaxed. We actually flip the analysis back to front. As in Cerasi et al. (2002), we specify an empirical model where the marginal benefits and costs of branching are estimated conditional on the observed market structure, not vice versa. Although from the theory we know that the ratio between $M B_{i j}$ and $M C_{i j}$ drives each bank's branching decision, when we move to the empirical specification, we estimate the (unconstrained) values of $M B_{i j}$ and $M C_{i j}$ that maximise the likelihood of observing a given number of branches for each bank in each local market. Note that both $M B_{i j}$ and $M C_{i j}$ are bank- and market-specific latent random variables. For identification reasons, we assume that the parameter $c i_{j}$, capturing the inverse degree of competition, only affects $M B_{i j}$ and is a linear function of market-specific demand variables and of an unobservable random component that changes across banks and markets; $M C_{i j}$ is instead a function of only bank-specific variables. The goodness of fit of our empirical specification is measured by the ability to predict the observed branching behaviour of banks in each market (see Section A.1 for the details of our identification strategy).

The novelty, here, compared with Cerasi et al. (2002) is that we exploit the same econometric specification to assess ex ante the impact of specific horizontal mergers on the degree of competition in the industry. To perform this impact analysis, we design a counterfactual exercise where we compare the status quo to an artificial scenario as if the merger was approved.

For a given merger, we undertake the following exercise: We sum the branches of the merging banks in the local market where the banks are active and estimate the model assuming that these new entities replace the old ones; we also assume that rivals do not change their branching size in any of the local markets in reaction to the merger. This yields the 
estimated degree of competition in the counterfactual scenario. From the comparison of the estimated measures of competition between the status quo and our counterfactual scenario, we derive an ex ante assessment of the impact of the proposed merger. From the sign of the difference of the two estimated parameters, cci, in the status quo and in the counterfactual scenario, we conclude whether the merger under evaluation is pro- or anti-competitive.

Our exercise implies that, although rival banks not involved in the merger do not change their branching behaviour directly, they might be affected indirectly through changes in market structure. Assume, for instance, that, following a procompetitive merger, the degree of competition cci falls. This affects the MB for all the banks in the market, also for the rival banks. Changing from one market structure to another, as we do in our counterfactual exercise, the estimated values of the marginal benefits and costs of branching vary for all banks and markets, not necessarily in a clearly predictable way, given the strong nonlinearity of the underlying model. We explore further this effect in the section devoted to the counterfactual exercise.

The greater advantage of our approach is that it requires a very limited amount of information to recover bank and branch profitability, that is, we just need to know the number of branches of each bank in a specific local market. We can list several reasons as to why it is convenient to use this approach. First, these are easily accessible data even at the disaggregate level, whereas we lack accounting profits at the local level for banks that are simultaneously active in several markets. Second, merger analysis uses the measures of concentration derived from market shares with respect to branches to detect potential restrictions to competition; our framework uses precisely the same data, without requiring additional information. Finally, the number of branches in a specific market may capture the expected long-term profitability. Because the opening and closing of branches is costly, a bank opens new branches only when it expects to recover the cost of its branching network with future profits. This profitability, although affected in the short term by contingent macro-economic factors, depends upon the long-lasting features of the market structure, such as the number of competitors or market size. Thus, a measure using information related to market structure, compared with accounting measures, such as accounting profits, better captures the idea of long-term profitability of a branching network.

\section{3 | DATA}

We apply our analysis to the banking industry in Italy and France. The reference market for the retail banking industry is the "local" market, namely 95 "departements" in France and 103 provinces in Italy. The appropriate unit of observation is the banking group rather than the individual bank: As a matter of fact, in both countries, different individual banks typically coordinate their decisions on branching within the group to which they belong.

Data on branches for each individual banking group are gathered in Italy from the site of Banca d'Italia and from Associazione Bancaria Italiana ( $\mathrm{ABI}$ ) for the name of the banks that belong to banking groups; in France, the information about branches for each of the important banking groups was kindly provided by Credit Agricole and Caisses d'Epargne. As a result, we have the information about branches in each local market for 25 Italian banking groups in 2006 and for nine French banking groups in 2007. In France, La Poste is included among the major banking groups as it is a significant competitor with a large and dispersed network. In contrast, we exclude Poste Italiane as it did not play, at the time of our analysis, a similar role. ${ }^{6}$ We assume that small groups with less than 300 branches or independent banks do not behave strategically, but adapt their branching behaviour residually. We, therefore, include them in the total number of branches in market $j$ because their competitive pressure, similar to a fringe in each local market, cannot be ignored, although we do not consider their strategic interaction within the equilibrium conditions.

For each local market, we have information on the total amount of deposits as a measure of the total volume of trade or market size. In addition, we collected information on market characteristics, namely "Per-capita loans" as a proxy for the economic activity in the local market, the proportion of "Rural areas" in each local market in France,

${ }^{6}$ In the merger decision, the Italian antitrust authority (see AGCM, 2006, 2007) has motivated the choice of excluding Poste Italiane from the relevant market of banking services due to the evidence of weak substitutability between financial services provided by Poste Italiane and banks. 
and a dummy indicating the presence of a "Big town" in the local market in Italy. These variables are taken from the national statistical institutes Institut national de la statistique et des études économiques (INSEE) for France and Istituto Nazionale di Statistica (ISTAT) for Italy.

Table B1 provides the descriptive statistics for the local markets, whereas Tables B2a and B2b for the banking groups. All statistics refer to 2007 in France and 2006 in Italy.

The average branching network size per banking group in each market is 19 in Italy, whereas it is 46 in France (the median value being 7 in Italy vs. 23 in France). The total number of branches in each local market is greater in France (441 vs. 237 in Italy), where in each market several large players are simultaneously active. The average market share calculated in terms of number of branches is about $11 \%$ in France and only $8 \%$ in Italy. The percentage of markets in which each banking group is present, that is, the variable "national reach", is on average smaller in Italy than in France, 70-100\%. On the contrary, the two countries are quite similar for what concerns the dispersion of branches and market shares within markets, as measured by the standard deviation.

In France, all banks have branches in each of the 95 local markets. In Italy, only six national banking groups (Banca Intesa, San Paolo IMI, Unicredito Italiano, Monte dei Paschi di Siena, Capitalia and Banca Nazionale del Lavoro) reach a national dimension with branches located in almost all 103 local markets, whereas the remaining groups have branches geographically concentrated in few local markets.

Finally, for each banking group, we observe the number of branches across all the markets in which the group is present. To capture coordination within the banking group across different local markets in our econometric analysis, we add a dummy indicating banks belonging to the same group. This has also the advantage that we automatically account for other differences across banks, such as mutual versus commercial banks without the need to add further dummies in the estimation.

Notice that we do not use accounting data. As a matter of fact, accounting measures of bank profits are rarely available at this level of disaggregation: Accounting statements provide data at the consolidated level of the banking group, that is, aggregate across all markets in which the group is active. For instance, suppose that Bank A owns branches in markets a and $b$ : The accounting statement provides only consolidated profits across the two markets, not the two profits separately, that is, the profit of Bank A in market $a$ and profit of Bank A in market $b$, as it would be required to recover the competitive behaviour of banks at the local level. Our empirical strategy provides a simple proxy for bank profit in each market, as expressed by the reduced form of profits in Equation (1), which is a function of the market share of the bank in each local market computed using the number of branches. Still our definition of bank profits in each local market may be correlated with the actual accounting profits.

\section{4 | COUNTERFACTUAL EXERCISE}

In this section, we propose a counterfactual exercise to measure the impact of a horizontal merger on the degree of competition at the local market level. We first estimate the degree of competition in the status quo; then, we build a counterfactual scenario, where we imagine a new entity arising from the approval of a specific merger and estimate the new degree of competition in that case. The statistical difference between the degrees of competition in the two cases across markets is the outcome of our counterfactual assessment. We apply our approach to several possible mergers in France and Italy.

\section{1 | Status quo}

The econometric model is estimated for a cross-section in 2006 for Italy and in 2007 for France. ${ }^{7}$

${ }^{7}$ Although we also have information about the geographic location of branches in 2005 for France and 2004 for Italy, we use them as a reference year for the econometric model (as explained in detail in Section A.1). 
The method of estimation is the maximum likelihood estimation (MLE) of the function in (A8) (see Section A1 in the Appendix) with the objective to find the best fit of the branching behaviour of banks in each local market. We supplement the likelihood function with an empirical specification for the random element in the marginal cost $m c_{i t}$ and for the parameter $c i_{j t}$ according to Equations (A9) and (A10) to help the identification of the model. In the empirical specification, we include a dummy for each banking group as an explanatory variable in $m c_{i t}$ : We assume that a greater percentage of branching costs is affected by the cost structure and the internal organisation of the bank, rather than by the characteristics of the market where the branch is located. ${ }^{8}$ As for the measure of competition, we include market-specific variables in $c i_{j t}$, such as "Per-capita loans" as proxy for the economic activity in the local market, the proportion of "Rural areas" in France, and a dummy indicating the presence of a "Big town" in Italy. We expect to find tougher competition in markets with higher per-capita loans and more densely populated areas, due to the greater incentive to compete for the marginal client when economic activity is more intense.

We present the results of the MLE in Table B3. All coefficients are statistically significant.

The signs of coefficients associated to the explanatory variables of $c c i_{j t}$ are coherent with our intuition: A negative sign indicates that competition is stronger ( $s m a l l e r ~ c c i{ }_{j t}$ ) in Italy in those markets where there is a large city ("Big town"). In addition, in both countries, competition increases with the level of economic activity, measured by per-capita loans ("Per-capita loans").

Table B4 shows the differences in competition, branching costs and profitability between the two countries. The average value of $c i_{j t}$ is higher in Italy than that in France (1.17 compared with 0.68 , where lower values imply stronger competition) meaning that local markets are on average more competitive in France than in Italy. Marginal costs of branching are lower in France than in Italy, and, moreover, they represent a smaller share of our estimated per-branch profits: The French banking system is not only more competitive but also each branch opportunity cost (as captured by $M C$ ) is lower.

In Tables B8a and B8b, we report the values of our estimated measure of competition for each local market. The parameter cci varies considerably across local markets. In densely populated areas, our measure cci takes smaller values indicating tougher competition. For instance, the value of cci is the lowest in Paris. In Italy, the overall variance of cci is greater. Notice that cci takes lower values in most Italian Northern provinces compared with that in Southern provinces. This result suggests that banking groups located in the north of Italy face greater competition compared with those located in the south (see Cerasi, Chizzolini, \& Ivaldi, 2000; Guiso, Sapienza, \& Zingales, 2006; and among others, for similar empirical evidence).

Notice that our profit function in (1) cannot be directly estimated because we do not have access to a measure of accounting profits per bank disaggregated at local market level. Hence, the goodness of our econometric specification must rely on the ability of the model to predict the observed branching behaviour of banks at the local market level. The goodness of fit of our econometric model can be assessed by comparing the predicted to the actual branching behaviour of banks in each local market. Table B5 reports the percentage of observations correctly classified. The model correctly predicts $84 \%$ of the observations in France and $75 \%$ in Italy.

\subsection{Counterfactual exercise}

We now design an artificial scenario as if a specific merger was approved. For this merger, we assume that the merging banks own the sum of the branches in each local market where the banks are active, whereas the rivals do not react to the merger and keep their branching network unchanged. The MLE method yields the estimated degree of competition in the counterfactual scenario. We then compare this new estimated measure of competition with the degree of competition in the status quo of Section 4.1.

\footnotetext{
${ }^{8}$ This assumption is supported by findings in Cerasi et al. (2002) where variables, such as the total number of employees and the distance of the branch from the location of bank's headquarters, significantly affect marginal branching costs. This implies that marginal branching costs are affected by bank specific rather than market-specific variables.
} 
We now apply our counterfactual method to several possible mergers in France and Italy.

\subsubsection{French mergers}

Two of the most important mergers that really occurred in France are the merger between Credit Mutuel (CM) and Credit Industriel Commercial (CIC) in 1998, and the one between Credit Agricole (CA) and Credit Lyonnais (CL) in 2004. Given that our French data set includes the number of branches owned by each separate banking group even before the merger, we can exploit this information to recover the premerger situation and measure the impact of the merger as if the merger had occurred within our observation period. In Table B6a, we report the relevant values in the status quo and in the counterfactual scenario.

The result of this exercise in terms of the estimated value of $c c i$ shows that these two mergers together have improved competition in the French banking industry. Table B8a (in Appendix B) displays the impact of the two mergers, as well as the differences (and their level of statistical significance) in the estimated values of the cci for each local market.

Adding also the merger between Banques Populaires (BP) and Caisses d'Epargne (CE), which was indeed approved after 2007, does not change the results. Even in this case, the parameter cci decreases compared with the premerger case (see the last row in Table B6a). This result indicates that the initial procompetitive effect of the merger still holds, even when considering a further increase in concentration. ${ }^{9}$

To fully understand our results, let us focus on a specific local market, such as Calvados. In Calvados, the degree of competition increases, as cci falls from 0.687 to 0.5446 following the mergers (assuming that $\mathrm{CA}$ merges with $\mathrm{CL}$ and $\mathrm{CM}$ with $\mathrm{CIC}$ ). The structure of that market changes from two large banking groups (La Poste with 169 branches and CA with 59) to a market where there are three large banking groups (La Poste with 169 branches and the two new entities due to the merger between $\mathrm{CA}$ and $\mathrm{CL}$ owning 78 branches and to the merger between $\mathrm{CM}$ and $\mathrm{CIC}$ owning 57 branches). Therefore, in this local market, competition is enhanced by the increase, from two to three, in the number of large competitors.

One important assumption in our exercise is that rival banks do not change their branching size at least in the short term. ${ }^{10}$ However, the merger must necessarily have an impact also on the ratio MB/MC of nonmerged banks, because they behave according to the equilibrium condition in (2). Let us explain this with the equilibrium branching condition for Banque National de Paris (BNP), which is a significant rival in the market of Calvados.

In Figure 2, we draw the curves $M B$ and $M C$ for BNP, a bank not directly involved in the mergers, using real values from the local market of Calvados. Total deposits are $S=10,070$ (million of Euro), whereas the total number of branches in the market is $N=433$. BNP has 20 branches in the status quo and keeps this number unchanged throughout the exercise. As we see from Figure 2 in order for the equilibrium condition to hold, that is, when $M B$ equals $M C, M C$ should decrease. We also assume that $S$ and $N$ do not change in the counterfactual exercise.

In reality, it is possible that rival banks do not remain passive and change their branching size in reaction to the merger. Suppose, for example, that $M C$ does not adjust as in Figure 2: For the equilibrium condition to be fulfilled that is for MB to be equal to MC, BNP would have to reduce its branching size. This would, in turn, reduce the effect on cci.

As a robustness check, we constrained the $M C$ of rivals to be constant throughout the counterfactual exercise in the econometric estimation. The procompetitive effect is still confirmed although its size is smaller (the results are available upon request).

\footnotetext{
${ }^{9}$ See Ivaldi (2006) for a detailed analysis of this merger.

${ }^{10}$ There is an empirical literature providing evidence that the anticompetitive impact of a merger may be considerably mitigated by the competitive reaction of nonmerging firms and by new entry in the market (see, e.g., the discussion in Draganska, Mazzeo, \& Seim, 2009, and evidence for the US banking industry in Adams et al., 2009). Berger, Bonime, Goldberg, and White (2004) provide evidence that, following horizontal mergers in the US banking industry, new banks enter and this effect dominates the reaction of incumbent banks.
} 


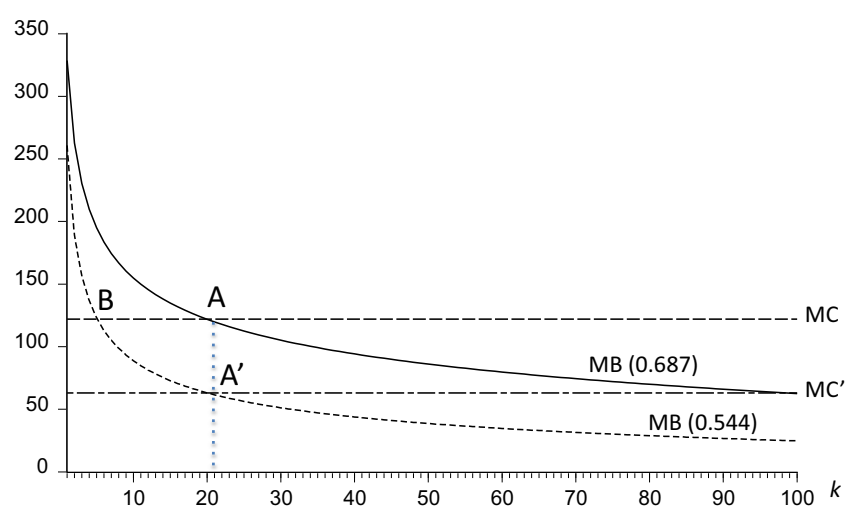

FIGURE 2 The graph represents the equilibrium (in Point A) for BNP, a bank not involved in mergers, in the local market of Calvados. Notes. Total deposits are $S=10,070$, and the total number of branches is $N=433$. The two mergers, CA with $\mathrm{CL}$ and $\mathrm{CM}$ with $\mathrm{CIC}$, are procompetitive. Hence, in Calvados, cci falls from 0.687 to 0.544 . As a result, the curve MB for BNP shifts down (dashed line). BNP does not react to the merger and keeps its status quo branching size constant at 20 branches: Thus, the line $M C$ must shift down so that the new equilibrium is in Point $A$. Otherwise for a given MC, BNP must reduce its branching network (Point B). BNP: Banque National de Paris; CA: Credit Agricole; CIC: Crédit Industriel Commercial; CL: Credit Lyonnais; CM: Credit Mutuel

As a further control, we computed the change in branching size of incumbent banks not involved in the mergers to see whether omitting their reaction may bias our results. In the French case, both mergers really occurred before our sample period: We, therefore, exploited information on the postmerger branching networks to control whether rival market shares changed in reaction to the mergers (the results are available upon request). The results exhibit the absence of rivals' reaction to the mergers, at least in the short term: Our conclusions are thus corroborated by this evidence.

\subsection{2 | Italian mergers}

We have applied our test to the Italian banking industry as well. Two of the most relevant aggregations in those years were Intesa (IN) merging with San Paolo IMI (SP) and UniCredito (UN) merging with Capitalia (CP). Notice that this exercise is "virtual" in our sample period because the merger actually occurred after the period in consideration, that is, at the end of 2007. In Table B6b, we provide the main values for the status quo and the counterfactual scenario.

The two mergers have an anticompetitive effect, as it results from the increase in the estimated value of cci compared with the status quo (last row in Table B6b). In Table B8b (in Appendix B), we report the differences (and their level of statistical significance) in cci in each local market.

The mergers of IN with SP and UN with CP have a negative impact on competition, as shown by the increase in the average value of cci across provinces from 1.17 to 1.27 (see Table B6b). In contrast with the French exercise, in Italy, the asymmetry of market shares rises following the mergers; the Gini index rises from 0.58 to 0.63 , the number of large banks declines from 3.59 to 3.16 and the $\mathrm{HHI}$ rises from 1,900 to 2,400. The impact of the two Italian mergers is clearly anticompetitive at the local market level (as it can be seen from the data in Table B8b): They, in fact, took place among top market players, and the overall effect has been a reinforcement of their already strong local market power. ${ }^{11}$

\footnotetext{
${ }^{11}$ This is coherent with the conclusions of the antitrust analysis of the two mergers (see AGCM, 2006, 2007). As a matter of fact, this argument has prompted the request by the antitrust to the new entities to dismiss several branches in the local markets where the increase in market power was considered to be excessive.
} 


\subsection{3 | Discussion of results}

The difference in the impact of Italian mergers compared with the French ones can be better understood by analysing their effects in each local market, as shown by changes in the different measures of concentration. Table B6a shows that the two mergers of $\mathrm{CA}$ with $\mathrm{CL}$ and $\mathrm{CM}$ with $\mathrm{CIC}$ in France reduce the average cci across local markets that falls from 0.68 to 0.54 indicating a rise in competition. Although the two mergers create two large banking groups in France, we observe a reduction in the Gini index from 0.57 to 0.53 and a rise in the number of banks with a market share above the average from 2.71 to 3.06. Notice that, even if the HHI rises due to larger banks increasing their market shares, according to our measure, the two French mergers have actually promoted competition. The beneficial impact on competition can be explained by the fact that those mergers reduce the asymmetry in the distribution of market shares (as it can be seen from the data in Table B8a). The merger between CA and CL, two large players with complementary branching networks, and the merger between two medium-sized players, such as $\mathrm{CM}$ with $\mathrm{ClC}$, have reinforced the presence of a number of large banks in all local markets and this has benefited competition. ${ }^{12}$

Our measure of competition partially replicates information contained in other well-known concentration measures and conveys additional information. As a matter of fact, the average correlation between our cci and the traditional measures at the local market level, reported in Table B7, is negative for the HHI and positive for the number of large banks in the market.

As for the Gini index, we observe opposite signs in the two countries: Greater equality in the market shares is associated with an increase in competition in France, but not in Italy. Thus, none of these traditional measures in isolation fully captures the information contained in our measure of competition.

To summarise, our econometric test shows that it would be misleading to base the impact assessment of a merger only on the change in the degree of concentration, as it used to be the case in merger policy before the reforms in Europe and in the US, which have limited the use of the dominance criteria as the sole test in merger assessment. ${ }^{13}$ In our simulation, for instance, such a rule would imply rejecting the French mergers, whereas according to our model they enhance competition. At the same time, note that the information required to compute our measure is precisely the same used in the calculation of local market concentration indexes, such as the HHI.

Looking at the landscape emerging from the two banking industries nowadays (we refer to Duijm \& Schoenmaker, 2018; Schoenmaker, 2015):

- France has larger banks, compared with those in Italy, with a greater weight in the international rankings (France has five among the largest banks in the world, whereas Italy only two).

- Both banking industries share a home bias, as banks mainly invest inside the country (only BNP for France and UN have more than $50 \%$ of their assets abroad).

- The French banking system is more fragmented compared with the Italian one, not just in our sample period; however, the degree of concentration in Italy has increased over the years, especially after 2007 when the two mergers object of our counterfactual exercise have taken place.

Focusing on the degree of concentration, one might conclude that Italy does not need further mergers as the level of competition is already low at the local market level. However, Italian banks are not exploiting the benefit of diversification by expanding abroad. Looking from an international perspective, promoting procompetitive mergers, even across borders, to increase competition in the domestic market might be beneficial.

\footnotetext{
${ }^{12}$ This argument is not new in the competition policy. The role of a large number of big players in enhancing competition is documented, for instance, by the debate around the proposal of mergers in the Canadian banking industry. Using Bank of Canada's words in response to Minister of Finance (23 June 2003): "In a given market, one player with a $45 \%$ market share can leave room for an acceptable level of competition, as long as there are two or three additional players with a certain critical mass who are also operating in the same market."

${ }^{13}$ See Shapiro (2010) and Gilbert and Rubinfeld (2011) for reviews of merger guidelines in the US and the EU before the reforms. They both argue how prereform guidelines emphasised the stand-alone role of pre- and post-merger HHI thresholds to challenge a merger. We refer to Ivaldi and Verboven (2005) for a discussion of the modern approach to merger evaluation.
} 


\section{5 | CONCLUDING REMARKS}

This paper proposes a counterfactual exercise to measure the impact of horizontal mergers on the degree of competition in the banking industry.

We first estimate the degree of competition in the French and Italian banking industries in a base year, given the observed market size, number of banks and individual banks' branching network size. We then create a counterfactual scenario where, keeping market size and total number of bank branches constant, we change the market shares, by summing the branches of the merging banks around the base year. We then re-estimate our measure of competition in this counterfactual setting and compare it to that obtained in the status quo. This exercise allows us to assess ex ante the impact of mergers on competition. We find examples of either pro- and anti-competitive mergers. In France, the mergers between Credit Agricole (CA) and Credit Lyonnais (CL) and between Credit Mutuel (CM) and Credit Industriel Commercial $(\mathrm{CIC})$ increase competition because they create in many local markets big rivals competing against a major player, such as La Poste. The opposite occurs in Italy where the mergers between, Intesa (IN) and San Paolo IMI (SP) in the north west, and between, UniCredito (UN) and Capitalia (CP) in the centre and south, create one unique big player in many local markets from banks that were originally medium-sized rivals.

We think that our exercise provides a useful guide to antitrust authorities when evaluating the short-term impact of horizontal mergers on competition and it is parsimonious in terms of data requirements. However, we recognise that our measure cannot fully anticipate the long-term effects, because we rule out new entries and keep the network size of rivals constant in response to the merger. Still we believe that our method offers a correct approximation of short-term effects of horizontal mergers in the banking industry.

\section{ACKNOWLEDGEMENTS}

We appreciated comments on a previous version circulated with the title "The Impact of Mergers on the Degree of Competition in the Banking Industry" by Jung-Hyun Ahn, Thorsten Beck, Rosella Creatini, Peter Davis, Hans Degryse, Stijn Ferrari, Robert Marquez, Sub Ramanarayanan, Elu Von Thadden, Wolf Wagner and participants at the ACE Workshop on Antitrust and Regulation, Fondazione Eni Enrico Mattei, Milan (October 2009), 2nd CEPREBC-UA Conference on competition in banking markets, Antwerp (December 2009), ZEW Conference on Quantitative Analysis in Competition Assessments, Mannheim (October 2010), FEBS 2012 Conference on Recent Developments in Financial Markets and Banking, London (June 2012) and 16th Centre for Competition and Regulatory Policy Workshop, Milan (July 2013). We acknowledge useful comments by anonymous referees. Chizzolini received financial support by Ente L. Einaudi and Cerasi by Fondo di Ateneo, Bicocca University.

\section{REFERENCES}

Adams, R., Johnson, R., \& Pilloff, S. (2009). Market structure after horizontal mergers: Evidence from the banking industry. Review of Industrial Organization, 35(3), 217-231.

AGCM-Autorita' Garante della Concorrenza e del Mercato (2006). C8027-Banca Intesa/San Paolo IMI. Provvedimento No. 16249.

AGCM-Autorita' Garante della Concorrenza e del Mercato (2007). C8660-Unicredito Italiano/Capitalia. Provvedimento No. 17283.

Bain, J. (1956). Barriers to new competition. Cambridge: Harvard University Press.

Barros, P., Bonfim, D., Kim, M., \& Martins, N. (2014). Counterfactual analysis of bank mergers. Empirical Economics, 46, 361-391.

Berger, A., Bonime, S., Goldberg, L., \& White, L. (2004). The dynamics of market entry: The effects of mergers and acquisitions on entry in the banking industry. Journal of Business, 77(4), 797-834.

Berger, A., Demirgiuc-Kunt, A., Levine, R., \& Haubrich, J. (2004). Bank concentration and competition: An evolution in the making. Journal of Money, Credit and Banking, 36(3), 433-451. 
Berry, S., \& Tamer, E. (2006). Identification in models of oligopoly entry. In R Blundell, W. Newey, \& T. Persson (Eds.), Advances in economics and econometrics, Econometric Society Monographs. Cambridge University Press.

Bikker, J., \& Haaf, K. (2002). Competition, concentration and their relationship: An empirical analysis of the banking industry. Journal of Banking and Finance, 26, 2191-2214.

Boone, J. (2008). A new way to measure competition. Economic Journal, 118, 1245-1261.

Boone, J., van Ours, J., van der Wiel, H. (2007), How (not) to measure competition. CEPR Discussion Paper No. 6275.

Brevoort, K., \& Hannan, T. (2006). Commercial lending and distance: Evidence from community reinvestment act data. Journal of Money, Credit and Banking, 38(8), 1991-2012.

Bresnahan, T., \& Reiss, P. (1991a). Empirical models of discrete games. Journal of Econometrics, 48, 57-81.

Bresnahan, T., \& Reiss, P. (1991b). Entry and competition in concentrated markets. Journal of Political Economy, 99, 977-1009.

Budzinski, O., \& Ruhmer, I. (2010). Merger simulation in competition policy: A survey. Journal of Competition Law and Economics, 6(2), 277-319.

Carletti, E., Ongena, S., Siedlarek, J. P., Spagnolo, G. (2015), The impact of merger legislation on bank mergers. Swiss Finance Institute Research Paper No. 16-33. http://dx.doi.org/10.2139/ssrn.2782040

Carletti, E., \& Vives, X. (2009). Regulation and competition policy in the banking sector. In X. Vives (Ed.), Competition policy in Europe, fifty years of the treaty of Rome (pp. 260-282). Oxford: Oxford University Press.

Cerasi, V., Chizzolini, B., Ivaldi, M. (2000). Branching and competitiveness across regions in the Italian banking industry. In M. Polo (Ed.), Industria Bancaria e Concorrenza, II Mulino (pp. 499-522).

Cerasi, V., Chizzolini, B., \& Ivaldi, M. (2002). Branching and competition in the European banking industry. Applied Economics, 34, 2213-2225.

Cetorelli, N. (1999). Competitive analysis in banking: Appraisal of the methodologies, economic perspectives. Federal Reserve Bank of Chicago, Chicago, Q1, 2-15.

Chizzolini, B. (2011). A multi-period model of competition in retail banking. Rivista Bancaria, Minerva Bancaria No. 3/2011, 3, 5-24.

Cohen, A., \& Mazzeo, M. (2007). Market structure and competition among retail depository institutions. Review of Economics and Statistics, 89(1), 60-74.

Dafny, L. (2009). Estimation and identification of merger effects: An application to hospital mergers. Journal of Law and Economics, 52(3), 523-550.

De Juan, R. (2008). Competition in local markets: Some evidence from the Spanish retail banking market. Review of Industrial Organization, 32(2), 145-162.

De Young, R., Evanoff, D., \& Molyneux, P. (2009). Mergers and acquisitions of financial institutions: A review of the post2000 literature. Journal of Financial Services Research, 36, 87-110.

Degryse, H., \& Ongena, S. (2005). Distance, lending relationship and competition. Journal of Finance, 60(1), $231-266$.

Degryse, H., \& Ongena, S. (2008). Competition and regulation in the banking sector: A review of the empirical evidence on the sources of bank rents. In A. Thakor \& A. Boot (Eds.), Handbook of financial intermediation and banking (pp. 483-554). Amsterdam, Netherlands: Elsevier.

Dick, A. (2007). Market size, service quality, and competition in banking. Journal of Money, Credit and Banking, 39(1), 49-81.

Draganska, M., Mazzeo, M., \& Seim, K. (2009). Addressing endogenous product choice in an empirical analysis of merger effects, mimeo: Chicago, Northwestern University.

Duijm, P., Schoenmaker, D. (2018). European bank mergers: Domestic and cross-border. Vox.eu. Available from https://voxeu. org/article/european-bank-mergers-domestic-and-cross-border

Focarelli, D., \& Panetta, F. (2003). Are mergers beneficial to consumers? Evidence from the market for bank deposits. American Economic Review, 93(4), 1152-1172.

Gilbert, R., Rubinfeld, D. (2011). Revising the horizontal merger guidelines: Lessons from the E.U. and the U.S. In M. Faure \& X. Zhang (Eds.), Competition policy and regulations: Recent developments in China, Europe and the U.S. Cheltenham, UK: Edward Elgar. Available from SSRN: http://ssrn.com/abstract=1660638

Guiso, L., Sapienza, P., Zingales, L. (2006). The cost of banking regulation. CEPR Discussion Paper No. 5864.

Ivaldi, M. (2006). Evaluation economique des effets d'une coordination eventuelle des groupes Banque Populaire et Caisse d'Epargne dans la banque de ditail. mimeo: Universite' de Toulouse.

Ivaldi, M., \& Verboven, F. (2005). Quantifying the effects from horizontal mergers in European competition policy. International Journal of Industrial Organization, 23, 669-691.

Molnar, J. (2008), Market power and merger simulation in retail banking. Bank of Finland Research Discussion Paper No. 4.

Petersen, M. A., \& Rajan, R. (2002). Does distance still matter? The information revolution in small business lending. Journal of Finance, 57(6), 2533-2570.

Sapienza, P. (2002). The effects of banking mergers an loan contracts. Journal of Finance, 57(1), 329-367.

Schaumans, C., \& Verboven, F. (2015). Entry and competition in differentiated products markets. Review of Economics and Statistics, 97(1), 195-209.

Shapiro, C. (2010). The 2010 horizontal merger guidelines: From hedgehog to fox in forty years. Antitrust Law Journal, 77, 49-99. 
Schoenmaker, D. (2015). The new banking union landscape in Europe: Consolidation ahead? Journal of Financial Perspectives, $3(2), 189-201$.

Zhou, X. (2008). Estimation of the impact of mergers in the banking industry with historical data on mergers. New Haven: Department of Economics, Yale University.

How to cite this article: Cerasi V, Chizzolini B, Ivaldi M. A test of the impact of mergers on bank competition. Economic Notes. 2019;1-27. https://doi.org/10.1111/ecno.12135

\section{APPENDIX A}

\section{Methodological appendix}

Starting from the reduced form of profit in Equation (1), the marginal benefit of opening an additional branch is given by

$$
M B_{i j t}=\frac{\partial \pi_{i j t}}{\partial k_{i j t}}=S_{j t} \frac{k_{i j t}^{c c i j t-1}}{\sqrt{N_{j t}}}\left(c c i_{j t}-\frac{k_{i j t}}{2 N_{j t}}\right) .
$$

The Nash equilibrium in the branching stage is given by bank i's best reply to rivals' choices of branching in each local market $j$ : This implies that, at the equilibrium, bank i's optimal branching size is set at the level where the marginal benefit of an additional branch $M B_{i j}$ equals the marginal cost of opening a new branch. To keep matters as simple as possible, we assume that an additional branch has a fixed marginal cost, $M C_{i j}{ }^{14}$

One of the following conditions must hold in equilibrium:

$$
\begin{array}{ll}
M B_{i j t}=M C_{i j t} & \text { when } k_{i j t}>1, \\
M B_{i j t}<M C_{i j t} & \text { when } k_{i j t}=1,
\end{array}
$$

where $k_{i j t}$ is the number of branches of bank $i$ in local market $j$ at time $t$.

To write the likelihood function for the branching behaviour of all the banks in our sample, we need to elaborate on conditions (A2) and (A3).

Notice that the marginal benefit of branching can be rewritten as

$$
M B_{i j t}=A_{i j t}-\gamma\left(\Delta k_{i j t}\right)
$$

where $\Delta k_{i j t}=\left(k_{i j t}-k_{i j t-1}\right)$ is the change in the branching size of bank $i$ from $t-1$ to $t$, and

$$
A_{i j t}=S_{j t} \frac{k_{i j t}^{c c i j t-1}}{\sqrt{N_{j t}}}\left(c c i_{j t}-\frac{k_{i j t-1}}{2 N_{j t}}\right)
$$

is a slight modification of $M B_{i j t}$, where we replace inside the brackets the number of branches at time $t$ with its lagged value $k_{i j t-1}$; whereas $\gamma(\cdot)$ is an increasing function of $\Delta k_{i j t}$, with $\gamma(0)=0$.

Let us now classify each observation (ijt) of bank $i$ in period $t$ in local market $j$ into one of the following four categories according to its branching behaviour:

\footnotetext{
${ }^{14}$ This is not the marginal cost of producing banking services, but the opportunity cost of opening a new branch.
} 
[a] "expanding multi-branch" bank if $\gamma(\cdot)>0$ and $k_{i j t}>1$;

[b] "static multi-branch" bank if $\gamma(\cdot)=0$ and $k_{i j t}>1$;

[c] "shrinking multi-branch" bank if $\gamma(\cdot)<0$ and $k_{i j t}>1$;

[d] "unit-branch" bank if $\gamma(\cdot)=0$ and $k_{i j t}=1$.

It is easy to see from (A4) that when $\gamma(\cdot) \geq 0$, then $A_{i j t} \geq M B_{i j t}$; whereas $A_{i j t}<M B_{i j t}$ when $\gamma(\cdot)<0$.

Furthermore, at time $t$, for all multibranch banks included in Cases [a]-[c], because $k_{i j t}>1$ condition (A2) must hold, that is, marginal benefit equals marginal costs of branching, whereas for all unit-branch banks in Case [d], because $k_{i j t}=1$ condition (A3) must hold: Marginal benefits must be lower than marginal costs of branching.

Then, the equality between $M B_{i j t}$ and $M C_{i j t}$ in condition (A2) and the inequality in condition (A3) can be substituted with inequalities between $A_{i j t}$ and $M C_{i j t}$ for all banks. Specifically $A_{i j t} \geq M C_{i j t}$ for all expanding or static multibranch banks, and $A_{i j t}<M C_{i j t}$ for all shrinking banks. This last condition applies also to all unit-branch banks because of condition (A3).

These modified conditions yield a simplified partitioning of observed banks into two subsets:

$$
\begin{aligned}
& E_{1}: \text { all banks in [a] and [b] so that } A_{i j t} \geq M C_{i j t}, \\
& E_{2}: \text { all banks in [c] and [d] so that } A_{i j t}<M C_{i j t} .
\end{aligned}
$$

To cast each observation in the probability space, we assume that the marginal branching cost $M C_{i j t}$ for bank $i$ in market $j$ at time $t$ is a random variable with known probability distribution. More specifically, we assume

$$
\ln M C_{i j t}=m c_{i t}+u_{i j t}
$$

where $m c_{i t}$ is the logarithm of the observable part of the marginal cost, whereas the error $u_{i j t}$ is a random variable with a standard normal distribution function $\Phi$. We assume $u_{i j t}$ to be independent across banks, $i$, and across markets, $j$.

Using the partitioning of observations in (A6), the probability that each observation (ijt) falls either in subset $E_{1 t}$ (expanding or static multibranch banks) or subset $E_{2 t}$ (shrinking multibranch or unit-branch banks) is given by

$$
\begin{aligned}
& \operatorname{Pr}\left\{(i j t) \in E_{1 t}\right\}=\operatorname{Pr}\left[M C_{i j t} \leq A_{i j t}\right]=\operatorname{Pr}\left(u_{i j t} \leq \ln A_{i j t}-m c_{i t}\right)=\Phi\left(\ln A_{i j t}-m c_{i t}\right), \\
& \operatorname{Pr}\left\{(i j t) \in E_{2 t}\right\}=\operatorname{Pr}\left[M C_{i j t}>A_{i j t}\right]=\operatorname{Pr}\left(u_{i j t}>\ln A_{i j t}-m c_{i t}\right)=1-\Phi\left(\ln A_{i j t}-m c_{i t}\right),
\end{aligned}
$$

exploiting the monotonicity property of the logarithm. Finally, we can write the likelihood function for all the observations in the data set as follows:

$$
\mathscr{L}=\sum_{(i j t) \in E_{1 t}} \ln \Phi\left(\ln A_{i j t}-m c_{i t}\right)+\sum_{(i j t) \in E_{2 t}} \ln \left[1-\Phi\left(\ln A_{i j t}-m c_{i t}\right)\right]
$$

We need some further assumptions about the functional form used to estimate the parameters, in particular:

$$
\begin{aligned}
& m c_{i t}=\theta+\sum_{m=1}^{M} \theta_{m} X_{m i t}, \\
& c c i_{j t}=\beta+\sum_{h=1}^{H} \beta_{h} Z_{h j t},
\end{aligned}
$$

where $X_{\text {mit }}$ are the $M$ observable bank-specific variables and $Z_{\text {hit }}$ the $H$ market-specific variables. Now, we are able to estimate the model with MLE and recover the observable part of the marginal branching costs $m c_{i t}$ and the measure of competition $c c i_{j t}$. 


\section{A.1.1 | Identification}

The estimated thresholds in similar latent variable models (see Berry \& Tamer, 2006; Bresnahan \& Reiss, 1991a, 1991b) are a measure of the level of profit that the marginal firm must earn to recover the sunk entry costs. In our model, the latent driving force is the relation between marginal benefits and costs of branching, conditional on the initial branching size.

From the equilibrium conditions in (2), such ratio equals 1 for all multibranch banks: Our estimated threshold will, however, differ from 1 by a random error term, which is bank and market specific. We cannot empirically identify whether the origin of such unobservable stochastic component comes from the costs or the benefit side of the equation. To disentangle demand effects from cost effects in our estimated measure of competition, we impose the following identifying restrictions on the adopted specification and on the parameters that are then jointly estimated with MLE.

Dropping the subscript $t$, the functional form of $M B_{i j}$ in (A1), and of $A_{i j}$ in (A5), requires the coefficients of $S_{j}$ and $N_{j}$ to be fixed for all markets. The parameter $c c i_{j}$, in turn, is assumed to be a function of market demand variables, whereas marginal costs only depend in our specification on bank-specific variables.

According to our empirical specification, in the status quo, we estimate the measure of competition $c c i_{j}$ for that market, and the marginal cost of branching of each incumbent bank for a given $S_{j}, N_{j}$ and given all observed $k_{i j}$. In the counterfactual scenario, we change the allocation of branches, by summing the branching networks of the banks involved in the merger. The values of $S_{j}, N_{j}$, the number of branches of the rival banks and the exogenous market demand variables in $c c i_{j}$ are kept unchanged. The restrictions we impose for identification, force any change in $M B_{i j}$, when moving from the status quo to the counterfactual scenario, to be captured only by changes in (the unconstrained coefficients in) $c c i_{j}$, that is, the elasticity of profits to branching.

\section{APPENDIX B}

TABLE B1 Descriptive statistics (across local markets)

\begin{tabular}{|c|c|c|c|c|c|}
\hline France (year 2007) & Mean & Median & Max & Min & Sta. Dev. \\
\hline Total deposits $(S)$ & $12,406.1$ & $8,091.4$ & $171,591.3$ & $1,691.1$ & $18,837.0$ \\
\hline Total branches $(N)$ & 441 & 373 & 1,485 & 91 & 253 \\
\hline Per-bank branches $(k)$ & 46 & 23 & 389 & 0 & 55 \\
\hline Market share $(k / N)$ & 10.61 & 5.36 & 69.13 & 0 & 12.61 \\
\hline National reach (\%) & 99.8 & 100 & 100 & 98 & 0.7 \\
\hline Number of local markets & \multicolumn{5}{|l|}{95} \\
\hline Italy (year 2006) & Mean & Median & Max & Min & Sta. Dev. \\
\hline Total deposits $(S)$ & $7,064.2$ & $3,647.6$ & $128,132.5$ & 442.8 & $15,323.6$ \\
\hline Total branches $(N)$ & 237 & 163 & 2,050 & 25 & 273 \\
\hline Per-bank branches $(k)$ & 19 & 7 & 435 & 1 & 34 \\
\hline Market share $(k / N)$ & 7.89 & 4.10 & 83.04 & 0.13 & 10.02 \\
\hline National reach (\%) & 70 & 71 & 100 & 20 & 25.76 \\
\hline Number of local markets & 103 & & & & \\
\hline
\end{tabular}

Source of data: The number of branches for individual banks by provinces in Italy is taken from www.bancaditalia.it, whereas we use the definition of banking groups by Associazione Bancaria Italiana (ABI). For France, the data were kindly provided by Credit Agricole and Caisses d'Epargne.

National reach is the percentage of markets over total markets, in which the bank is present. All monetary values are expressed in (million of) Euro. 
TABLE B2a Descriptive statistics (at banking group level, 2007)

\begin{tabular}{lll}
\hline France & National reach (\%) & \# Branches \\
\hline La Poste & 100 & 15,581 \\
\hline Credit Agricole & 100 & 6,238 \\
\hline Caisses d'Epargne & 100 & 4,312 \\
\hline Credit Mutuel & 100 & 3,111 \\
\hline Banques Populaires & 100 & 2,475 \\
\hline Societe Generale & 100 & 2,204 \\
\hline Banque National de Paris & 100 & 2,154 \\
\hline Credit Lyonnais & 100 & 1,947 \\
\hline Credit Industriel Commercial & 98 & 1,692 \\
\hline Mean & 99.8 & $4,412.67$ \\
\hline Sta. Dev. & 0.7 & $4,429.78$
\end{tabular}

Source of data: The number of branches for banking groups by departments was kindly provided by Credit Agricole and Caisses d'Epargne.

National reach is the percentage of markets over total markets, in which the bank is present.

TABLE B2b Descriptive statistics (at banking group level, 2006)

\begin{tabular}{|lll|}
\hline Italy & National reach (\%) & \# Branches \\
\hline San Paolo IMI & 98 & 3,171 \\
\hline Banca Intesa & 99 & 3,029 \\
\hline Unicredito Italiano & 97 & 3,028 \\
\hline Capitalia & 98 & 2,013 \\
\hline Monte dei Paschi di Siena & 98 & 1,908 \\
\hline Banco Popolare di Verona & 58 & 1,221 \\
\hline Banche Popolari Unite & 60 & 1,205 \\
\hline Banca Popolare Emilia Romagna & 51 & 1,175 \\
\hline Banca Antonveneta & 84 & 1,007 \\
\hline Banco Popolare Italiana & 72 & 901 \\
\hline Banca Lombarda e Piemontese & 48 & 787 \\
\hline Banca Nazionale del Lavoro & 100 & 731 \\
\hline Banca Popolare di Milano & 38 & 713 \\
\hline Banca CR Firenze & 20 & 534 \\
\hline Banca Popolare di Vicenza & 43 & 524 \\
\hline Carige & 54 & 508 \\
\hline Credito Emiliano & 71 & 470 \\
\hline Mean & 70 & 1,348 \\
\hline Sta. Dev. & 25.8 & 936 \\
\hline SOún & & \\
\hline
\end{tabular}

Source of data: The number of branches for individual banks by provinces in Italy is taken from www.bancaditalia.it, whereas we use the definition of banking groups by Associazione Bancaria Italiana (ABI).

National reach is the percentage of markets over total markets, in which the bank is present. 
TABLE B3 Estimation (status quo) of components of the degree of competition cci

\begin{tabular}{|lll|}
\hline Constant & France & Italy \\
\hline Rural area & $0.662^{*}$ & $1.243^{*}$ \\
\hline Big town & $(0.000)$ & $(0.000)$ \\
\hline Per-capita loans & 0.082 & - \\
\hline Banking group dummies & $(0.192)$ & $-0.340^{*}$ \\
\hline Log likelihood & - & $(0.000)$ \\
\hline \# Observations & & $-0.003^{*}$ \\
\hline
\end{tabular}

The model is estimated with maximum likelihood estimation (MLE), where the likelihood function is defined in (A8), supplemented by the specific forms (A9) and (A10) for the regression of $m c$ and $c c i$ (see Section A.1). The parameter cci is identified through market-specific explanatory variables (Rural area, Big town and Per-capita loans), whereas the marginal cost $m c$ is identified through bank-specific explanatory variables (a dummy for each banking group). Inside brackets the $p$-values.

${ }^{*}$ Significant at $10 \%$ level.

TABLE B4 Estimated (status quo) average values at market level across banking groups

\begin{tabular}{llllll} 
France & Mean & Median & Max & Min & Sta. Dev. \\
\hline$c c i$ & 0.68 & 0.69 & 0.71 & 0.32 & 0.04 \\
$m c$ & 42.67 & 39.20 & 99.38 & 22.45 & 22.71 \\
\hline Profit/branch & 149.49 & 115.99 & $2,240.58$ & 18.20 & 208.34 \\
\hline Italy & Mean & Median & Max & Min & Sta. Dev. \\
\hline$c c i$ & 1.17 & 1.19 & 1.23 & 0.64 & 0.10 \\
\hline$m c$ & 242.51 & 216.90 & 502.23 & 132.89 & 100.22 \\
\hline Profit/branch & 400.06 & 297.03 & $2,829.97$ & 88.55 & 393.54 \\
\hline
\end{tabular}

Note. The model is estimated with maximum likelihood estimation (MLE), where the likelihood function is defined in (A8), supplemented by the specific forms (A9) and (A10) for the regression of $m c$ and cci (see Section A.1). All monetary values are expressed in (million of) Euro.

TABLE B5 Goodness of fit (status quo) (predicted vs. actual observations in \%)

\begin{tabular}{|c|c|c|c|c|c|c|c|}
\hline \multirow{2}{*}{$\begin{array}{l}\text { France } \\
\text { Actual }\end{array}$} & \multicolumn{2}{|l|}{ Predicted } & & \multirow{2}{*}{$\begin{array}{l}\text { Italy } \\
\text { Actual }\end{array}$} & \multicolumn{2}{|l|}{ Predicted } & \\
\hline & $d k<0, k=1$ & $d k \geq 0, k>1$ & & & $d k<0, k=1$ & $d k \geq 0, k>1$ & \\
\hline$d k<0, k=1$ & 9.74 & 12.99 & 22.74 & $d k<0, k=1$ & 5.22 & 19.58 & 24.8 \\
\hline \multirow[t]{2}{*}{$d k \geq 0, k>1$} & 2.9 & 74.36 & 77.26 & $d k \geq 0, k>1$ & 5.06 & 70.15 & 75.2 \\
\hline & 12.65 & 87.35 & 100 & & 10.28 & 89.72 & 100 \\
\hline
\end{tabular}

The correct predictions are obtained by summing the values The correct predictions are obtained by summing the in the cells along the main diagonal (84.1\%) values in the cells along the main diagonal (75.4\%)

Note. The model is estimated with maximum likelihood estimation (MLE), where the likelihood function is defined in (A8), supplemented by the specific forms (A9) and (A10) for the regression of $m c$ and $c c i$ (see Section A.1). 
TABLE B6a Impact of mergers on competition and market structure (average values at national level)

\begin{tabular}{lllll} 
France & $c c i$ & Gini index & HHI & Number of large banks \\
\hline Status quo & 0.68 & 0.57 & 2,400 & 2.71 \\
\hline Mergers: $C A+C L$ and $C M+C I C$ & $(0.04)$ & $(0.12)$ & $(0.08)$ & $(0.90)$ \\
\hline Mergers: $C A+C L, C M+C I C$ and CE + BP & 0.54 & 0.53 & 2,600 & 3.06 \\
& $(0.03)$ & $(0.12)$ & $(0.08)$ & $(0.82)$ \\
\hline & 0.55 & 0.50 & 2,700 & 3.48 \\
\hline
\end{tabular}

Note. The Herfindahl-Hirschman Index $(\mathrm{HHI})$ is the sum of squared market shares. The number of large banks is the number of banks with a market share above the average. The Gini index measures the inequality between market shares and is defined as $\left(2 / n^{2} \bar{y}\right) \sum_{i=1}^{n} i\left(y_{i}-\bar{y}\right)$, where $y_{i}$ are the market shares computed on branches and $n$ is the number of banks. Standard deviations are inside brackets.

CA: Credit Agricole; CE: Caisses d'Epargne; CIC: Crédit Industriel Commercial; CL: Credit Lyonnais; CM: Credit Mutuel; BP: Banques Populaires.

TABLE B6b Impact of mergers on competition and market structure (average values at national level)

\begin{tabular}{lllll}
\hline Italy & cci & Gini index & HHI & Number of large banks \\
\hline Status quo & 1.17 & 0.58 & 1,900 & 3.59 \\
\hline Mergers: IN + SP and UN + CP & $(0.09)$ & $(0.09)$ & $(0.11)$ & $(1.51)$ \\
& 1.27 & 0.63 & 2,400 & 3.16 \\
\hline
\end{tabular}

Note. The Herfindahl-Hirschman Index (HHI) is the sum of squared market shares. The number of large banks is the number of banks with a market share above the average. The Gini index measures the inequality between market shares and is defined as $\left(2 / n^{2} \bar{y}\right) \sum_{i=1}^{n} i\left(y_{i}-\bar{y}\right)$, where $y_{i}$ are the market shares computed on branches and $n$ is the number of banks. Standard deviations are inside brackets.

Note. CP: Capitalia; IN: Intesa; SP: San Paolo IMI; UN: Unicredito.

TABLE B7 Correlation between competition and measures of market structure

\begin{tabular}{lllll}
\hline France & $c c i$ & HHI & Gini index & Number of large banks \\
\hline$c c i$ & 1.00 & 0.54 & 0.59 & -0.49 \\
HHI & - & 1.00 & 0.93 & -0.72 \\
\hline Gini & - & - & 1.00 & -0.70 \\
\hline Number of large banks & - & - & - & 1.00 \\
\hline Italy & $c c i$ & HHI & Gini index & Number of large banks \\
cci & 1 & 0.11 & -0.07 & -0.21 \\
\hline HHI & - & 1.00 & 0.53 & -0.01 \\
\hline Gini & - & - & 1.00 & -0.20 \\
\hline Number of large banks & - & - & - & 1.00 \\
\hline
\end{tabular}

Note. The Herfindahl-Hirschman Index (HHI) is the sum of squared market shares. The number of large banks is the number of banks with a market share above the average. The Gini index measures the inequality between market shares and is defined as $\left(2 / n^{2} \bar{y}\right) \sum_{i=1}^{n} i\left(y_{i}-\bar{y}\right)$, where $y_{i}$ are the market shares computed on branches and $n$ is the number of banks. The matrix is symmetric.

\section{Additional tables}

We list, here, the detailed results for each French and Italian local market. 


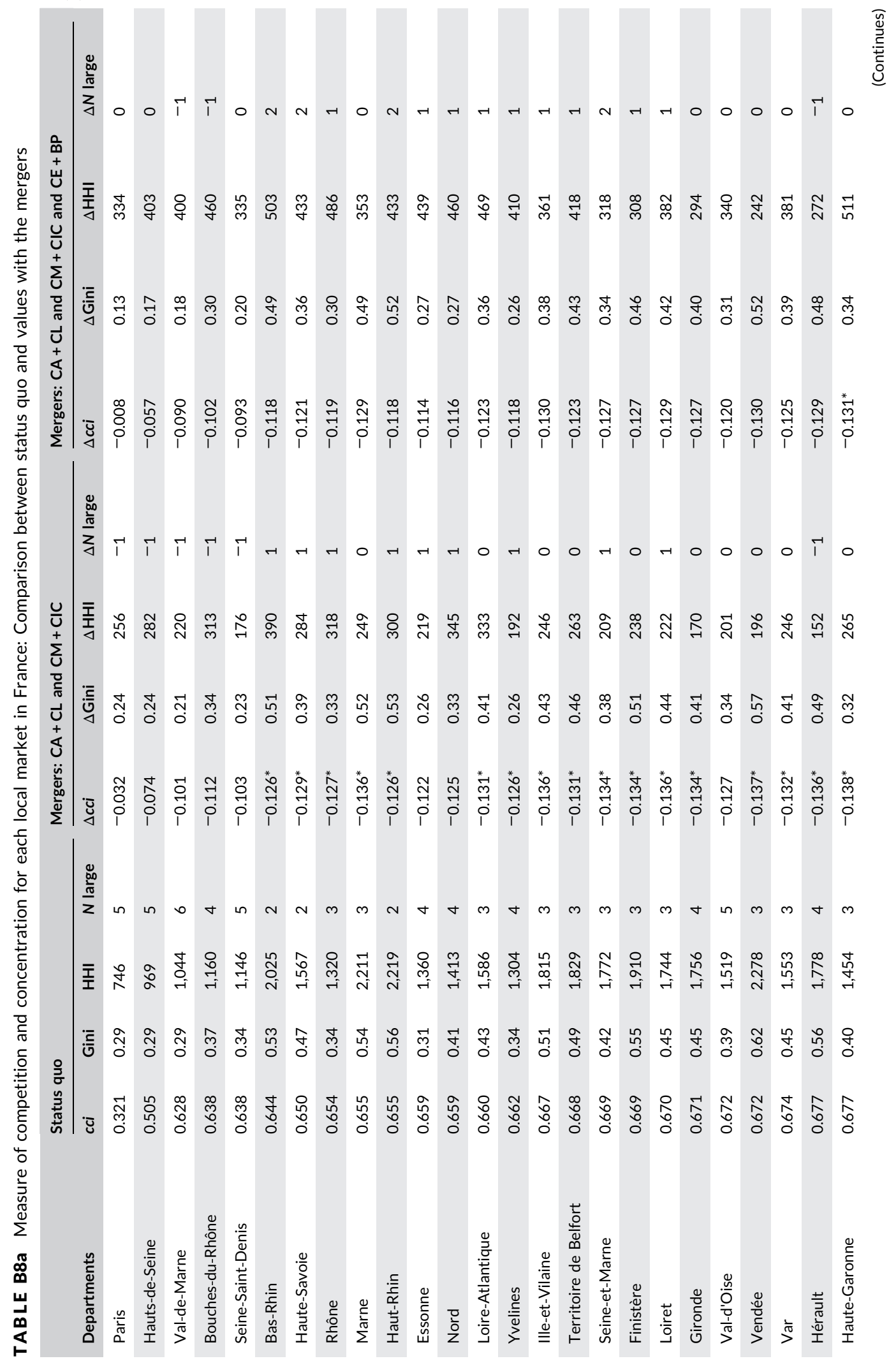




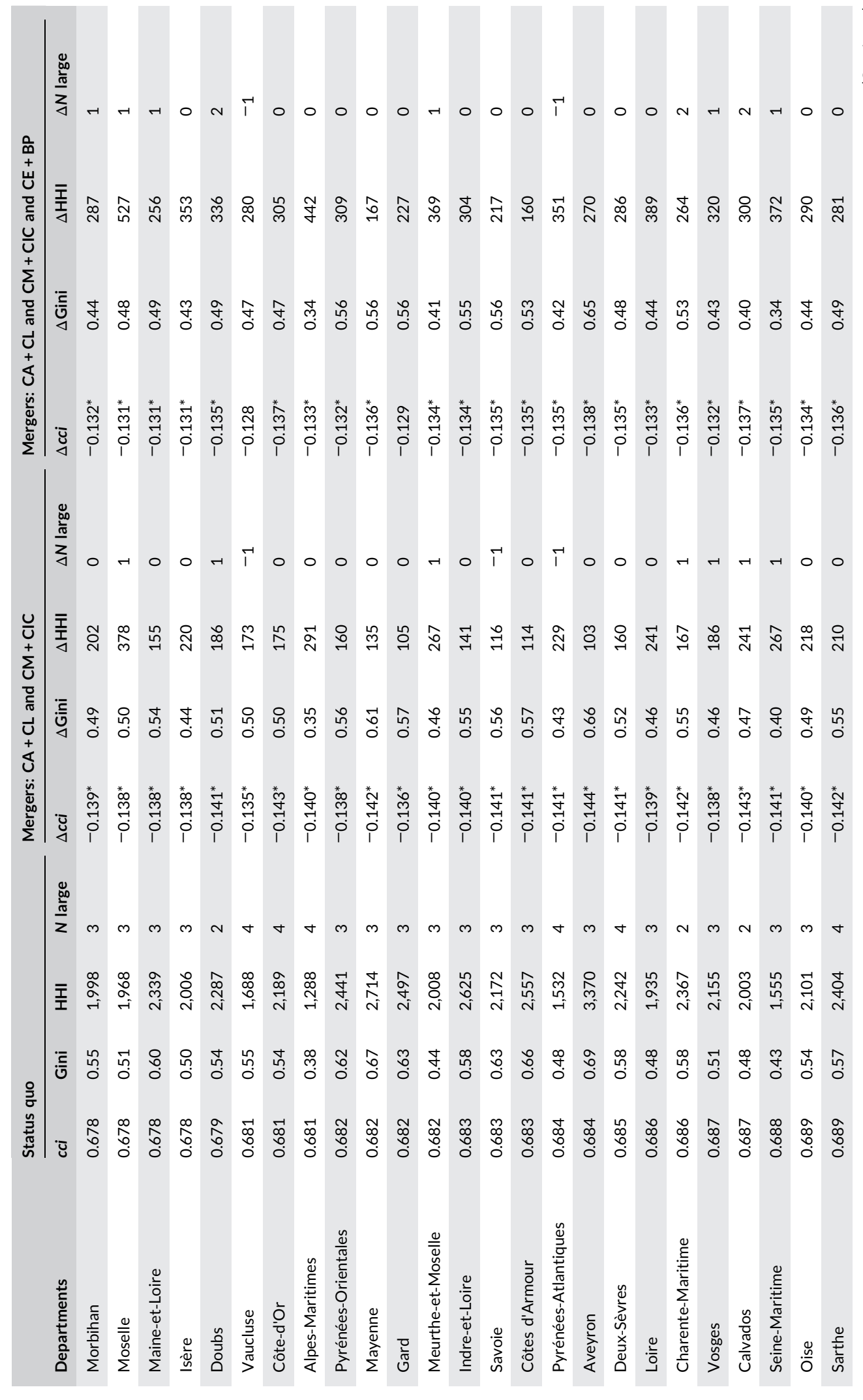




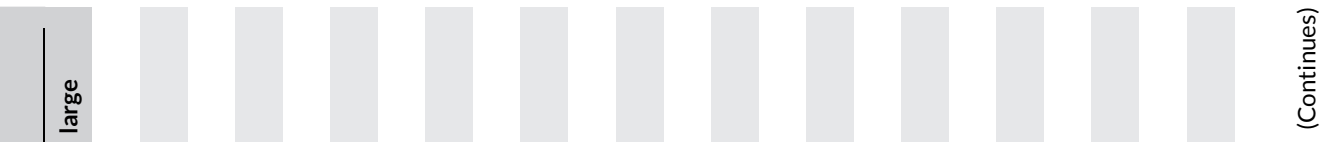

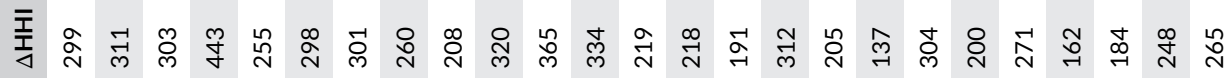

站 ư

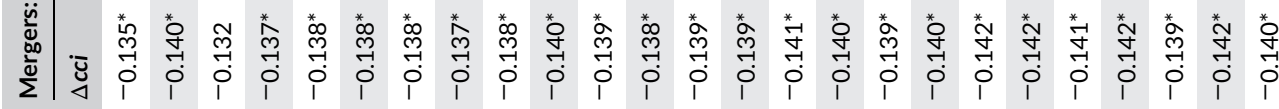

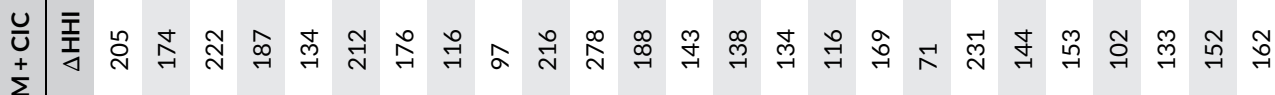

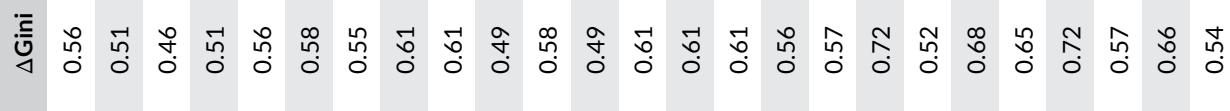

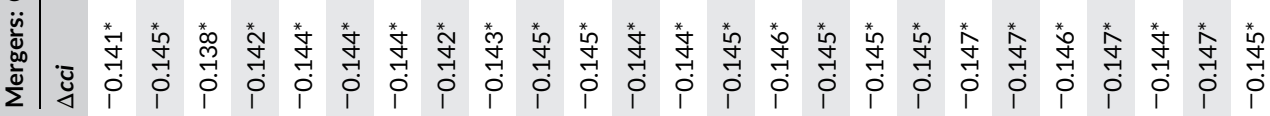
$\frac{\substack{0 \\ \frac{0}{\sigma 0}}}{2}$

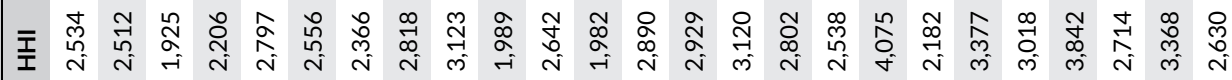

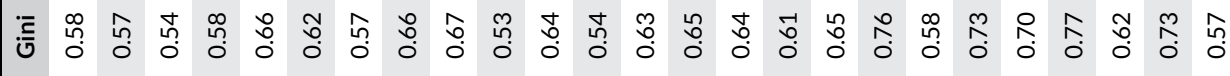
ㅇํㅁ

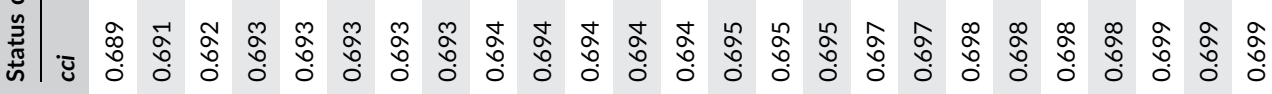




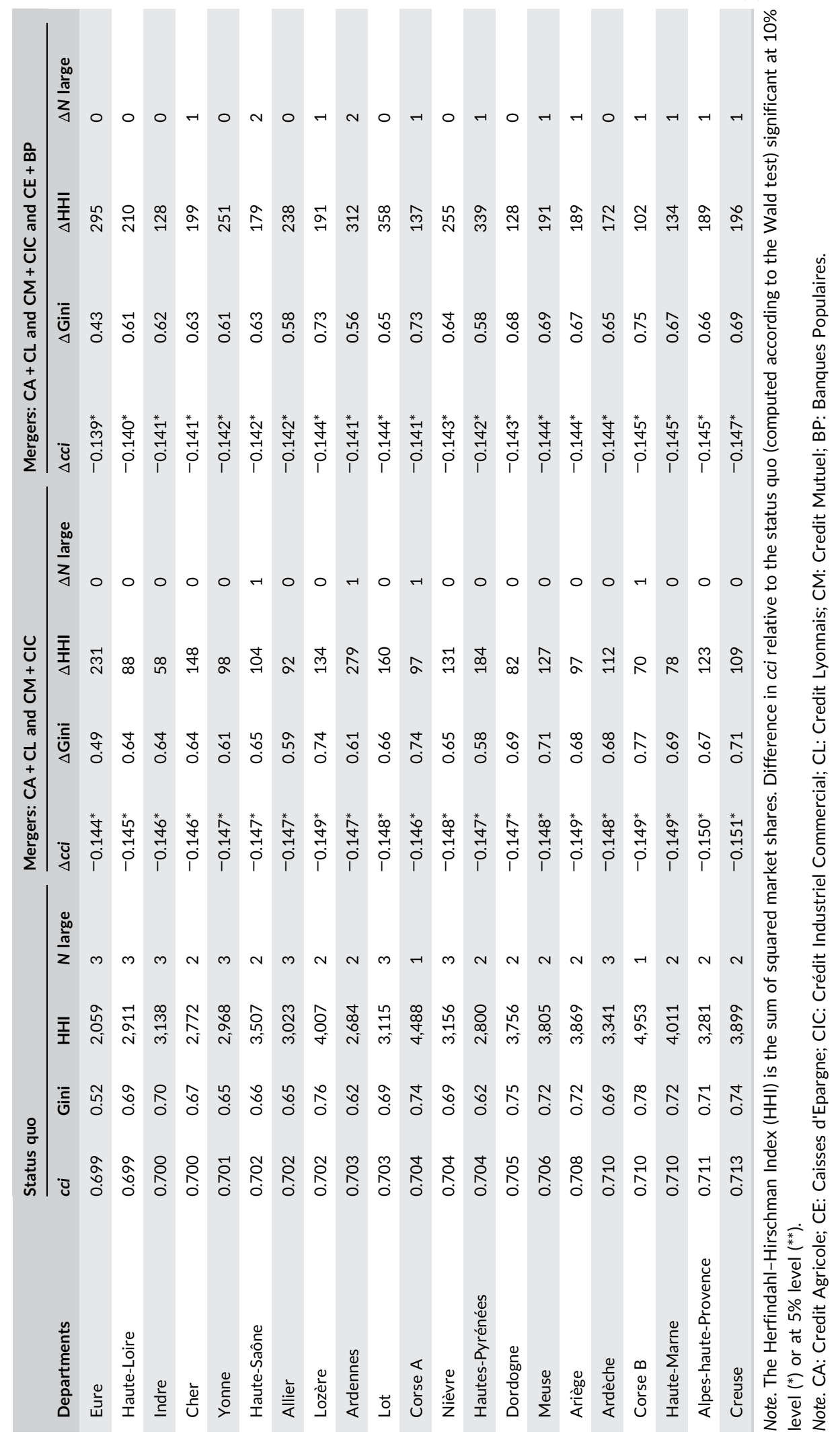


TABLE B8b Measure of competition and concentration for each local market in Italy: Comparison between status quo and values with the mergers

\begin{tabular}{|c|c|c|c|c|c|c|c|c|}
\hline \multirow[b]{2}{*}{ Province } & \multicolumn{4}{|c|}{ Status quo } & \multicolumn{4}{|c|}{ Mergers: IN + SP and UN + CP } \\
\hline & $c c i$ & Gini & $\mathrm{HHI}$ & $N$ large & $\Delta c c i$ & $\Delta$ Gini & $\Delta \mathrm{HHI}$ & $\Delta \mathrm{N}$ large \\
\hline Milano & 0.643 & 0.5 & 1,020 & 5 & 0.049 & 0.59 & 467 & -1 \\
\hline Roma & 0.763 & 0.53 & 950 & 6 & 0.082 & 0.64 & 647 & -2 \\
\hline Torino & 0.843 & 0.7 & 2,828 & 4 & 0.104 & 0.77 & 1,445 & -2 \\
\hline Napoli & 0.877 & 0.57 & 2,727 & 6 & 0.114 & 0.69 & 1,428 & -2 \\
\hline Firenze & 1.106 & 0.64 & 1,390 & 2 & $0.079^{*}$ & 0.67 & 81 & 2 \\
\hline Siena & 1.119 & 0.77 & 4,155 & 2 & $0.082^{*}$ & 0.75 & 19 & 0 \\
\hline Bergamo & 1.134 & 0.6 & 1,794 & 5 & $0.086^{* *}$ & 0.64 & 368 & -1 \\
\hline Bolzano & 1.134 & 0.65 & 355 & 1 & $0.086^{* *}$ & 0.71 & 87 & -1 \\
\hline Bologna & 1.134 & 0.59 & 1,380 & 4 & $0.086^{* *}$ & 0.64 & 312 & -1 \\
\hline Brescia & 1.137 & 0.59 & 1,649 & 4 & $0.087^{* *}$ & 0.66 & 223 & 0 \\
\hline Padova & 1.141 & 0.7 & 2,962 & 6 & $0.088^{* *}$ & 0.75 & 907 & -2 \\
\hline Modena & 1.145 & 0.61 & 1,383 & 4 & $0.09^{* *}$ & 0.65 & 238 & 0 \\
\hline Trento & 1.148 & 0.74 & 2,078 & 3 & $0.09^{* *}$ & 0.74 & 208 & -1 \\
\hline Rimini & 1.148 & 0.54 & 715 & 2 & $0.09^{* *}$ & 0.61 & 236 & 1 \\
\hline Mantova & 1.149 & 0.56 & 1,690 & 4 & $0.09^{* *}$ & 0.61 & 216 & 0 \\
\hline Parma & 1.151 & 0.59 & 1,666 & 7 & $0.091^{* *}$ & 0.67 & 549 & -3 \\
\hline Prato & 1.152 & 0.61 & 1,340 & 5 & $0.091^{* *}$ & 0.61 & 109 & 0 \\
\hline Reggio Emilia & 1.152 & 0.58 & 1,303 & 6 & $0.091^{* *}$ & 0.63 & 357 & 0 \\
\hline Forlì e Cesena & 1.155 & 0.61 & 801 & 2 & $0.092^{* *}$ & 0.64 & 100 & 0 \\
\hline Vicenza & 1.155 & 0.64 & 1,711 & 6 & $0.092^{* *}$ & 0.67 & 355 & -1 \\
\hline Verona & 1.156 & 0.68 & 1,832 & 5 & $0.092^{* *}$ & 0.73 & 285 & -1 \\
\hline Ancona & 1.158 & 0.46 & 661 & 2 & $0.093^{* *}$ & 0.51 & 201 & 1 \\
\hline Treviso & 1.16 & 0.62 & 1,256 & 5 & $0.093^{* *}$ & 0.69 & 471 & -1 \\
\hline Udine & 1.162 & 0.6 & 2,302 & 5 & $0.094^{* *}$ & 0.71 & 1,451 & -1 \\
\hline Ravenna & 1.162 & 0.62 & 794 & 4 & $0.094^{* *}$ & 0.65 & 125 & -1 \\
\hline Biella & 1.165 & 0.66 & 1,889 & 2 & $0.095^{* *}$ & 0.72 & 557 & -1 \\
\hline Sondrio & 1.165 & 0.57 & 147 & 0 & $0.095^{* *}$ & 0.66 & 71 & 0 \\
\hline Lodi & 1.166 & 0.58 & 2,968 & 3 & $0.095^{* *}$ & 0.67 & 1,501 & 0 \\
\hline Lucca & 1.17 & 0.61 & 1,571 & 4 & $0.096^{* *}$ & 0.58 & 38 & 0 \\
\hline Macerata & 1.17 & 0.38 & 439 & 1 & $0.096^{* *}$ & 0.38 & 96 & 0 \\
\hline Pesaro e Urbino & 1.172 & 0.59 & 882 & 5 & $0.097^{* *}$ & 0.7 & 584 & -1 \\
\hline Piacenza & 1.173 & 0.57 & 2,089 & 3 & $0.097^{* *}$ & 0.65 & 542 & -1 \\
\hline Lecco & 1.174 & 0.54 & 651 & 3 & $0.098^{* *}$ & 0.61 & 305 & -1 \\
\hline Cremona & 1.176 & 0.62 & 2,209 & 3 & $0.098^{* *}$ & 0.68 & 885 & -1 \\
\hline Varese & 1.18 & 0.61 & 1,432 & 4 & $0.099^{* *}$ & 0.66 & 336 & 0 \\
\hline Como & 1.18 & 0.63 & 1,564 & 4 & $0.099^{* *}$ & 0.71 & 1,341 & 0 \\
\hline Pordenone & 1.181 & 0.61 & 2,511 & 4 & $0.099^{* *}$ & 0.73 & 1,910 & -1 \\
\hline
\end{tabular}


TABLE B 8 b (Continued)

\begin{tabular}{|c|c|c|c|c|c|c|c|c|}
\hline \multirow[b]{2}{*}{ Province } & \multicolumn{4}{|c|}{ Status quo } & \multicolumn{4}{|c|}{ Mergers: $\mathrm{IN}+\mathrm{SP}$ and $\mathrm{UN}+\mathrm{CP}$} \\
\hline & $c c i$ & Gini & $\mathrm{HHI}$ & $N$ large & $\Delta c c i$ & $\Delta$ Gini & $\Delta \mathrm{HHI}$ & $\Delta \mathrm{N}$ large \\
\hline Arezzo & 1.181 & 0.7 & 1,380 & 2 & $0.099^{* *}$ & 0.69 & 28 & 0 \\
\hline Pistoia & 1.181 & 0.62 & 1,881 & 2 & $0.099^{* *}$ & 0.6 & 32 & 0 \\
\hline Venezia & 1.182 & 0.62 & 3,053 & 7 & $0.1^{* *}$ & 0.74 & 1,972 & -3 \\
\hline Pescara & 1.182 & 0.55 & 1,504 & 2 & $0.1^{* *}$ & 0.63 & 322 & 1 \\
\hline Perugia & 1.184 & 0.63 & 1,598 & 3 & $0.1^{* *}$ & 0.64 & 267 & 0 \\
\hline Alessandria & 1.184 & 0.54 & 1,523 & 6 & $0.1^{* *}$ & 0.59 & 408 & -1 \\
\hline Cuneo & 1.185 & 0.7 & 2,038 & 4 & $0.1^{* *}$ & 0.7 & 114 & 0 \\
\hline Genova & 1.185 & 0.56 & 1,442 & 6 & $0.101^{* *}$ & 0.63 & 308 & -2 \\
\hline Pisa & 1.186 & 0.62 & 1,189 & 2 & $0.101^{* *}$ & 0.63 & 35 & 0 \\
\hline Novara & 1.188 & 0.58 & 1,431 & 4 & $0.101^{* *}$ & 0.62 & 329 & -1 \\
\hline Livorno & 1.189 & 0.65 & 1,944 & 2 & $0.102^{* *}$ & 0.64 & 73 & 1 \\
\hline Ascoli Piceno & 1.19 & 0.53 & 1,168 & 4 & $0.102^{* *}$ & 0.61 & 516 & 0 \\
\hline Asti & 1.192 & 0.65 & 580 & 3 & $0.102^{* *}$ & 0.67 & 67 & 0 \\
\hline Rovigo & 1.192 & 0.68 & 6,082 & 4 & $0.103^{* *}$ & 0.72 & 1,746 & -1 \\
\hline Savona & 1.195 & 0.6 & 2,515 & 4 & $0.103^{* *}$ & 0.63 & 292 & 0 \\
\hline $\begin{array}{l}\text { Verbania Cusio } \\
\text { Ossola }\end{array}$ & 1.195 & 0.6 & 1,183 & 2 & $0.103^{* *}$ & 0.65 & 276 & 0 \\
\hline Belluno & 1.195 & 0.68 & 2,137 & 3 & $0.103^{* *}$ & 0.72 & 330 & -1 \\
\hline Grosseto & 1.196 & 0.67 & 2,801 & 2 & $0.104^{* *}$ & 0.67 & 19 & 0 \\
\hline Ferrara & 1.196 & 0.58 & 473 & 2 & $0.104^{* *}$ & 0.61 & 97 & 1 \\
\hline Pavia & 1.198 & 0.53 & 1,730 & 4 & $0.104^{* *}$ & 0.61 & 1,106 & 0 \\
\hline Vercelli & 1.198 & 0.68 & 2,565 & 4 & $0.104^{* *}$ & 0.75 & 1,075 & -1 \\
\hline Gorizia & 1.199 & 0.51 & 3,869 & 4 & $0.104^{* *}$ & 0.63 & 2,266 & -2 \\
\hline Trieste & 1.199 & 0.48 & 2,066 & 4 & $0.104^{* *}$ & 0.61 & 1,050 & -1 \\
\hline Massa & 1.2 & 0.56 & 1,680 & 4 & $0.105^{* *}$ & 0.48 & 46 & -1 \\
\hline Teramo & 1.202 & 0.53 & 1,111 & 1 & $0.105^{* *}$ & 0.63 & 564 & 0 \\
\hline Terni & 1.202 & 0.69 & 2,349 & 4 & $0.105^{* *}$ & 0.66 & 129 & 0 \\
\hline Aosta & 1.203 & 0.65 & 3,384 & 2 & $0.105^{* *}$ & 0.69 & 952 & 0 \\
\hline La Spezia & 1.204 & 0.58 & 2,318 & 3 & $0.106^{* *}$ & 0.59 & 147 & 0 \\
\hline Sassari & 1.205 & 0.76 & 4,637 & 2 & $0.106^{* *}$ & 0.78 & 188 & 0 \\
\hline Imperia & 1.208 & 0.56 & 1,804 & 5 & $0.107^{* *}$ & 0.63 & 665 & -2 \\
\hline Viterbo & 1.209 & 0.57 & 1,858 & 4 & $0.107^{* *}$ & 0.53 & 197 & -1 \\
\hline Cagliari & 1.209 & 0.72 & 3,514 & 4 & $0.107^{* *}$ & 0.76 & 335 & -1 \\
\hline Chieti & 1.209 & 0.48 & 1,018 & 2 & $0.107^{* *}$ & 0.52 & 186 & 0 \\
\hline Ragusa & 1.209 & 0.48 & 836 & 1 & $0.107^{* *}$ & 0.56 & 217 & 1 \\
\hline Bari & 1.21 & 0.49 & 1,124 & 7 & $0.107^{* *}$ & 0.61 & 590 & -2 \\
\hline L'Aquila & 1.212 & 0.68 & 2,126 & 3 & $0.108^{* *}$ & 0.66 & 110 & 1 \\
\hline Catania & 1.215 & 0.48 & 959 & 3 & $0.109^{* *}$ & 0.55 & 289 & 0 \\
\hline
\end{tabular}


TABLE B 8 b (Continued)

\begin{tabular}{|c|c|c|c|c|c|c|c|c|}
\hline \multirow[b]{2}{*}{ Province } & \multicolumn{4}{|c|}{ Status quo } & \multicolumn{4}{|c|}{ Mergers: IN + SP and UN + CP } \\
\hline & cci & Gini & $\mathrm{HHI}$ & $N$ large & $\Delta c c i$ & $\Delta$ Gini & $\Delta \mathrm{HHI}$ & $\Delta \mathrm{N}$ large \\
\hline Palermo & 1.216 & 0.54 & 1,830 & 1 & $0.109^{* *}$ & 0.61 & 372 & 1 \\
\hline Campobasso & 1.216 & 0.5 & 1,606 & 4 & $0.109^{* *}$ & 0.6 & 920 & -1 \\
\hline Rieti & 1.218 & 0.69 & 1,908 & 3 & $0.11^{* *}$ & 0.73 & 413 & -1 \\
\hline Trapani & 1.218 & 0.41 & 1,140 & 4 & $0.11^{* *}$ & 0.43 & 288 & 0 \\
\hline Latina & 1.219 & 0.54 & 1,847 & 3 & $0.11^{* *}$ & 0.56 & 353 & 0 \\
\hline Salerno & 1.22 & 0.57 & 1,838 & 6 & $0.11^{* *}$ & 0.6 & 496 & -1 \\
\hline Siracusa & 1.22 & 0.52 & 1,204 & 2 & $0.11^{* *}$ & 0.61 & 420 & 1 \\
\hline Matera & 1.22 & 0.6 & 2,475 & 3 & $0.11^{* *}$ & 0.53 & 129 & 0 \\
\hline Lecce & 1.221 & 0.5 & 796 & 3 & $0.11^{* *}$ & 0.58 & 320 & 0 \\
\hline Foggia & 1.221 & 0.47 & 1,136 & 6 & $0.11^{* *}$ & 0.53 & 305 & 0 \\
\hline Messina & 1.221 & 0.46 & 1,231 & 3 & $0.11^{* *}$ & 0.53 & 416 & 1 \\
\hline Catanzaro & 1.222 & 0.29 & 1,297 & 6 & $0.111^{* *}$ & 0.3 & 293 & -1 \\
\hline Frosinone & 1.223 & 0.63 & 2,185 & 3 & $0.111^{* *}$ & 0.69 & 435 & -1 \\
\hline Caltanissetta & 1.224 & 0.56 & 1,956 & 3 & $0.111^{* *}$ & 0.56 & 117 & 1 \\
\hline Taranto & 1.225 & 0.39 & 1,428 & 5 & $0.111^{* *}$ & 0.45 & 455 & 0 \\
\hline Cosenza & 1.225 & 0.52 & 2,068 & 4 & $0.112^{* *}$ & 0.55 & 199 & -1 \\
\hline Potenza & 1.225 & 0.54 & 1,028 & 3 & $0.112^{* *}$ & 0.53 & 101 & 0 \\
\hline Oristano & 1.225 & 0.83 & 6,288 & 1 & $0.112^{* *}$ & 0.83 & 53 & 0 \\
\hline Agrigento & 1.226 & 0.52 & 1,989 & 4 & $0.112^{* *}$ & 0.61 & 632 & -1 \\
\hline Nuoro & 1.226 & 0.85 & 7,003 & 1 & $0.112^{* *}$ & 0.86 & 64 & 0 \\
\hline Avellino & 1.226 & 0.65 & 2,742 & 3 & $0.112^{* *}$ & 0.68 & 392 & 0 \\
\hline Caserta & 1.227 & 0.63 & 5,207 & 5 & $0.112^{* *}$ & 0.72 & 2,203 & -1 \\
\hline Isernia & 1.227 & 0.41 & 2,384 & 4 & $0.112^{* *}$ & 0.56 & 1,568 & -1 \\
\hline Crotone & 1.228 & 0.47 & 2,620 & 4 & $0.112^{* *}$ & 0.46 & 219 & 0 \\
\hline Enna & 1.228 & 0.5 & 2,370 & 4 & $0.112^{* *}$ & 0.51 & 158 & 0 \\
\hline Benevento & 1.229 & 0.51 & 1,747 & 3 & $0.113^{* *}$ & 0.52 & 267 & 0 \\
\hline Brindisi & 1.229 & 0.44 & 1,262 & 3 & $0.113^{* *}$ & 0.51 & 637 & -1 \\
\hline Reggio Calabria & 1.23 & 0.47 & 1,967 & 5 & $0.113^{* *}$ & 0.47 & 373 & -1 \\
\hline Vibo Valentia & 1.232 & 0.51 & 2,832 & 5 & $0.114^{* *}$ & 0.51 & 153 & 0 \\
\hline
\end{tabular}

Note. The Herfindahl-Hirschman Index (HHI) is the sum of squared market shares. Difference in cci relative to the status quo (computed according to the Wald test) significant at $10 \%$ level $\left(^{*}\right)$ or at $5 \%$ level $\left(^{* *}\right)$.

CP: Capitalia; IN: Intesa; SP: San Paolo IMI; UN: UniCredito.

\section{Non-technical Summary}

We propose a new test to measure the impact of mergers among banks on competition before their approval. The test just uses publicly available information on the number of branches of individual banking groups in each local market. We compare two scenarios: the status-quo where branching networks by banks are those actually observed, with a counterfactual scenario, where the branching network of the new entity is the sum of the branches of the banks involved in the horizontal merger. 
In both scenarios we estimate the degree of competition using a structural model of branching behavior of banks. The statistical difference between the two estimated measures of competition quantifies the impact of the merger.

We apply our test to approved mergers in Italy and France. The results point to anti-competitive mergers in Italy, while pro-competitive mergers in France.

In one case the merger reduces substantially the number of large players, at least, in some local markets; in another case the merger creates a new entity, large enough to compete with the incumbent banks in markets with small incumbents. These contrasting effects cannot be fully anticipated by focusing just on the changes in market concentration (as measured by the Herfindahl-Hirschman Index for instance), since in both cases market concentration increases.

We believe that our test provides useful guidance to competition authorities who must assess the impact of mergers in industries where the retail network is important. 